\title{
THE
}

\section{TERPENE CHEMISTRY OF EASTERN HEMLOCKS RESISTANT TO HEMLOCK WOOLLY ADELGID}

\author{
E. Alexa McKenzie \\ Joseph S. Elkinton \\ Richard A. Casagrande \\ University of Rhode Island, casa@uri.edu \\ Evan L. Preisser \\ University of Rhode Island, preisser@uri.edu \\ Mark Mayer
}

Follow this and additional works at: https://digitalcommons.uri.edu/bio_facpubs

The University of Rhode Island Faculty have made this article openly available.

Please let us know how Open Access to this research benefits you.

This is a pre-publication author manuscript of the final, published article.

Terms of Use

This article is made available under the terms and conditions applicable towards Open Access

Policy Articles, as set forth in our Terms of Use.

\section{Citation/Publisher Attribution}

MacKenzie, E. Alexa, Joseph S. Elkinton, Richard A. Casagrande, Evan L. Preisser, and Mark Mayer. "Terpene Chemistry of Eastern Hemlocks Resistant to Hemlock Woolly Adelgid." J Chem Ecol. 2014 Sep; 40(9):1003-12. doi: 10.1007/s10886-014-0495-0. 
TERPENE CHEMISTRY OF EASTERN HEMLOCKS RESISTANT TO HEMLOCK WOOLLY ADELGID

\author{
E. ALEXA MCKENZIE ${ }^{1}$, JOSEPH S. ELKINTON ${ }^{1,2 *}$, \\ RICHARD A. CASAGRANDE ${ }^{3}$, EVAN L. PREISSER ${ }^{4}$, and MARK MAYER ${ }^{5}$ \\ ${ }^{1}$ Program in Organismic and Evolutionary Biology, University of Massachusetts, Amherst, MA 01003; \\ ${ }^{2}$ Department of Environmental Conservation, University of Massachusetts, Amherst, MA 01003; ${ }^{3}$ Department of \\ Plant Sciences and Entomology, University of Rhode Island, Kingston, RI 02881; ${ }^{4}$ Department of Biological \\ Sciences, University of Rhode Island, Kingston, RI 02881; ${ }^{5}$ Division of Plant Industry, Phillip Alampi Beneficial \\ Insect Laboratory New Jersey Department of Agriculture, Trenton, NJ 08625
}

\begin{abstract}
Recent studies have identified a small number of individual eastern hemlock trees that demonstrate relative resistance to the introduced sap-feeding insect, the hemlock woolly adelgid. Using gas chromatography, we compared concentrations of twenty-two terpenoids in susceptible and relatively resistant trees, both in the forest and in propagated cuttings in a common-garden setting. Terpenoid concentrations were higher in twig tissue of resistant versus susceptible trees, across six sampling dates and at both sites. These changes may be particularly important because the hemlock woolly adelgid feeds on twig tissue. Because the common-garden cuttings were free of herbivores, the higher terpenoid concentrations are interpreted as a constitutive defense. Increased levels of monoterpenes and sesquiterpenes imply an overall increase in the input of carbon precursors to both terpenoid synthesis pathways.
\end{abstract}

Key Words - Tsuga canadensis, Adelges tsugae, terpene chemistry, host resistance, invasive species, growthdefense balance. 


\section{INTRODUCTION}

The discovery, development, or maintenance of herbivore-resistant genetic lineages can play a key role in the conservation of plant species attacked by introduced pests (Bentz et al. 2002; Burdon 2010; Ingwell and Preisser 2011; Mattson 1986; Reis et al. 2004; Schoettle et al 2012). Here we address factors that may be linked to resistance to the hemlock woolly adelgid (Adelges tsugae Annand, abbrev. HWA) in rare individuals of eastern hemlock (Tsuga canadensis). Adelges tsugae is a sessile, piercing-sucking insect introduced to the eastern United States from Japan (Havill et al. 2006; McClure 1991). While HWA causes limited damage to Tsuga hosts in its native range of East Asia and the American Pacific Northwest (Lagalante and Montgomery 2003; Montgomery et al. 2009; Oten et al. 2012), HWA poses a serious threat to the host species, eastern hemlock (T. canadensis) and Carolina hemlock (T. caroliniana), in its introduced range (McClure 1991; Orwig and Foster 1998; Orwig et al. 2002). Eastern and Carolina hemlock are also colonized by a second introduced piercing-sucking insect, the elongate hemlock scale (EHS, Fiorinia externa), which contributes to hemlock decline, but may deter later co-infestation by HWA (Gomez et al. 2012).

HWA feeds on nutrients in the xylem ray parenchyma cells, and prefers the most recent flush of growth (McClure 1989; Young et al. 1995). Infestation by HWA has been shown to alter xylem growth and water relations in eastern hemlock (Domec et al. 2013; Gonda-King et al. 2012). This effect is associated with a hypersensitive response (Radville et al. 2011), reduced photosynthetic productivity (Domec et al. 2013), and mobilization of nitrogen to new-growth tissues (Gomez et al. 2012). In addition, infested hemlocks display a local increase in phenolic compounds (Pezet et al. 2013), and a simultaneous increase in monoterpene volatilization and decrease in stored mono- and sesquiterpenes (Broeckling and Salom 2003; Pezet et al. 2013). A 10- to 100-fold increase in methyl salicylate, a molecule involved in the salicylic acid signaling pathway for systemic acquired resistance (Vlot et al. 2009), has also been detected in adelgid-infested eastern hemlocks (Pezet et al. 2013). In other systems, some of these responses have been linked to plant defense against herbivores or pathogens (Wu and Baldwin 2010); in eastern and Carolina hemlock, however, infestation by HWA leads to tree decline and eventual mortality (McClure 1991; Paradis 2011).

Resistance to HWA has been observed in rare individuals of eastern hemlock found growing vigorously in otherwise adelgid-devastated hemlock stands (Caswell et al. 2008; Ingwell and Preisser 2011). Heritable resistance was assessed by propagating cuttings from these trees and control (i.e., HWA-susceptible) eastern hemlocks. Once 
the cuttings were established, both control and resistant cuttings were inoculated with HWA and adelgid settlement and survival was assessed. Adult HWA densities were significantly lower on the resistant cuttings than on the susceptible cuttings (Ingwell and Preisser 2011), supporting the hypothesis that some rare eastern hemlock individuals possess a degree of HWA resistance, and implying that this resistance is manifest as antibiosis.

One previous study (Ingwell et al. 2009) has examined eastern hemlocks that were tentatively identified as HWA-resistant. Although potassium levels were higher in HWA-resistant versus HWA-susceptible eastern hemlocks, there were no other differences in nutritional content (Ingwell et al. 2009). Various studies have examined traits that correlate with HWA susceptibility both within and among Tsuga species. In Carolina hemlock, lower levels of the lipid hexacosanol may be associated with decreased HWA susceptibility (Kaur 2009). Across Tsuga species, thicker epicuticular wax at the point of HWA stylet insertion (Oten et al. 2012), higher levels of the terpenes alpha-pinene, alpha-humulene, beta-caryophyllene, and germacrene D, and lower levels of the terpene isobornyl acetate (Lagalante and Montgomery 2003), are associated with decreased HWA susceptibility. A comparable degree of intraspecific variation in terpene profiles have been observed among ornamental varietals of eastern hemlock (Lagalante et al. 2007), suggesting that natural populations of eastern hemlock may also vary in their terpene profiles.

We explored one potential mechanism of HWA resistance in eastern hemlock by conducting an acrossseason study of terpene profiles in the identified resistant parent trees and their clonal sapling offspring, versus those of mature and sapling HWA-susceptible eastern hemlocks. Because terpenes act as toxins and semiochemicals in the complex oleoresin that serves as the primary defense of conifers against herbivory, they are likely candidates for allelochemical resistance to HWA. Phenolics, also key in conifer defense chemistry, were not addressed in this study as they appear at very low concentrations when measured by the following method of solvent extraction, filtration, and gas chromatography. Lagalante and Montgomery (2003) suggested that different terpenoids, acting either individually or in combination, may participate directly in plant resistance by serving as HWA feeding stimulants or deterrents. Alternatively, other processes in the resistant trees may influence monoterpene and sesquiterpene concentrations, so that our observed terpene chemistry would provide indirect evidence about the resistance mechanism. Our study intends to provide a thorough profile of monoterpenes and sesquiterpenes present in each season and detect both univariate and multivariate correlations to resistance status. 


\section{METHODS AND MATERIALS}

Resistant and control mature trees in a New Jersey forest (NJ), and resistant and control sapling trees (i.e., rooted cuttings) in a common garden at the University of Rhode Island (URI), were sampled at six intervals from May 2012 to June 2013. Solvent extraction and gas chromatography (GC) were used to measure the concentration of each identified terpene in each tree. Terpene profiles were analyzed for concentration differences in single terpenes, as well as for multivariate differences across all terpenes present.

Study Site 1: New Jersey “Bulletproof Stand.” Previous research (Ingwell and Preisser 2011) identified eight putatively HWA-resistant eastern hemlocks growing on state-owned land adjacent to the Delaware Water Gap National Recreation Area in northern New Jersey, of which trees \#1-5 have been tested for resistance by bioassay of clonal saplings (Ingwell and Preisser 2011). Trees \#1-5 were sampled at all collection dates, and trees \#6 and \#7 were sampled beginning in October 2012 (Table 1). All of the sampled individuals are mature trees growing within a $0.25 \mathrm{~km}$ radius in a hemlock, white pine, and mixed hardwood forest.

Control trees were selected within a $5 \mathrm{~km}$ radius of the resistant trees, to control for microclimate and soil conditions, as well as genetic variation expected over longer distances. Trees in moderate to good current health, as observed by presence of current season growth, were selected to control for effects of tree health decline on terpene

chemistry. To ensure that the trees were in fact HWA-susceptible, we only used trees that were infested with HWA or had evidence of needle loss due to previous infestations. We initially used five control trees for balanced replication with the five resistant trees we initially sampled. Beginning in October 2012, fifteen to twenty-one control trees were used to improve statistical power. Different control trees were used across collection dates (Table 1).

Study Site 2: University of Rhode Island Common Garden. Sapling clones of resistant trees \#1-5 were established at the University of Rhode Island by propagating cuttings from the mature trees (Caswell et al. 2008; Ingwell and Preisser 2011). Cuttings of $8 \mathrm{~cm}$ of terminal growth were collected from the parent trees in January 2007 and rooted using a treatment of Dip-N-Grow plant hormone solution (Griffin Greenhouse Supplies, Tewksbury, Massachusetts). Saplings were established outdoors in three planting boxes, each $3.8 \mathrm{~m}^{2}$ and $30 \mathrm{~cm}$ deep, filled with a 1:1 mix of soil and compost, supplemented with soil from an established hemlock stand. Planting boxes were exposed to full sun and sheltered from wind by proximity to a low building on the south and east sides. Five saplings were successfully established from each of five parent trees, yielding twenty-five resistant saplings in total 
(Table 1). All saplings were free of herbivores.

For control trees, nineteen genetically individual saplings were established adjacent in the planting boxes, with equal sun exposure and no herbivores (Table 1). Ten saplings were collected from the Quabbin forest (New Salem, MA, USA) in 2009. An additional nine saplings were purchased from a Michigan nursery (Van Pine's Nursery, West Olive, MI, USA), originally grown from seed collected in Indiana County, Pennsylvania, in autumn 2009.

Extraction of Terpenes from Plant Material. Samples of hemlock tissue for chemical analysis were collected at seasonal intervals from May 2012 to June 2013 at both sites (Table 1). Each month's collection at a site was performed on a single day in the afternoon daylight hours. Each sample was collected by cutting the terminal flush of growth (current-year growth) from ten to fifteen tips scattered over two to four mature branches or circularly around one sapling tree, totaling approximately $75 \mathrm{~cm}$ of tissue. Samples were promptly flash-frozen in liquid nitrogen and transported on dry ice until storage at $-80^{\circ} \mathrm{C}$ in the laboratory.

From each sample, a total of $18 \mathrm{~cm}$ of growth was selected at random for extraction. HWA on the sample were counted $(\mathrm{HWA} / \mathrm{cm})$, and EHS was rated categorically for density $(0=$ no EHS/cm, $1=0-1 \mathrm{EHS} / \mathrm{cm}, 2=1-10$ EHS/cm, 3 = 11-100 EHS/cm). Needles were separated from twigs with tweezers. Approximately $1 \mathrm{~mL}$ volume of needles, or ca. thirty needles, were selected at random and placed in a pre-weighed vial. Twigs were ground under liquid nitrogen and placed in a second pre-weighed vial. Tissue dry weight was determined following extractions and two to six weeks in a $75^{\circ} \mathrm{C}$ drying oven.

One milliliter of methyl tert-butyl ether (MTBE) was applied to each vial as an extraction solvent. Tissue was extracted for 16-19 hours with continuous agitation. Extracts were treated with $0.3 \mathrm{~mL}$ of $0.1 \mathrm{M}$ aqueous ammonium carbonate, filtered on silica gel, activated carbon, and magnesium sulfate (3:1:2 ratio), and eluted with $0.5 \mathrm{~mL}$ hexanes. Filtered eluates were stored at $-20^{\circ} \mathrm{C}$ in glass vials capped with PTFE/silicone septa.

Quantification of Terpenoid Compounds. Terpene compounds in samples were quantified by gas chromatography with flame ion detection (Hewlett-Packard Agilent 6890, running Agilent ChemStation software). Separations were performed on an Agilent HP-5 capillary column, non-polar with crosslinked 5\% phenyl / 95\% methyl siloxane, $0.25 \mu \mathrm{m}$ film thickness, $0.32 \mathrm{~mm}$ diameter, $30 \mathrm{~m}$ length. The column was trimmed by $8 \mathrm{~cm}$ during

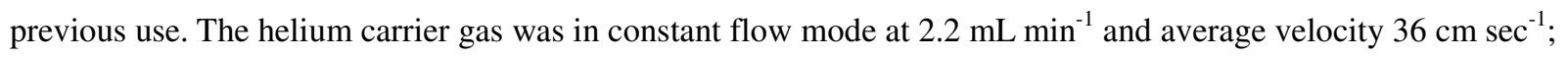
sample was injected with split ratio of $3: 1$, split flow of $6.5 \mathrm{~mL} \mathrm{~min}^{-1}$, and total flow of $11.1 \mathrm{~mL} \mathrm{~min}^{-1}$. The injection 
volume was $1 \mathrm{uL}$ at inlet temperature of $250^{\circ} \mathrm{C}$. The $\mathrm{GC}$ oven temperature was programmed to start at $60^{\circ} \mathrm{C}$ and rise to $158^{\circ} \mathrm{C}$ with holds at $64^{\circ} \mathrm{C}, 100^{\circ} \mathrm{C}$, and $126^{\circ} \mathrm{C}$ to improve separation of compounds, followed by burn-off at $200^{\circ} \mathrm{C}$ to maintain instrument cleanliness (Table 2). The flame-ion detector was set at $300^{\circ} \mathrm{C}$, with hydrogen flow at $30 \mathrm{~mL}$ $\mathrm{min}^{-1}$, air flow at $300 \mathrm{~mL} \mathrm{~min}^{-1}$, and nitrogen makeup flow at $25 \mathrm{~mL} \mathrm{~min}{ }^{-1}$. The detector began data collection after 3 minutes of solvent cut-time.

Raw quantity (pA sec) was calculated for each terpene by software integration of peak area on the chromatogram (Hewlett-Packard ChemWare). Concentration $\left(\mu \mathrm{g} \mathrm{mL} \mathrm{m}^{-1}\right)$ was calculated using experimentallydetermined calibration curves. Calibration curves were determined individually for those compounds that were available as analytical standards (Sigma-Aldrich, Saint Louis, MO): $\alpha$-pinene, camphene, sabinene, $\beta$-pinene, myrcene, $\alpha$-phellandrene, p-cymene, limonene, eucalyptol, camphor, piperitone, bornyl acetate, $\beta$-caryophyllene, and $\alpha$-humulene. Averaged calibration curves of structurally similar terpenoids were used when no commercial standard was available: tricyclene, $\gamma$-muurolene, germacrene D, $\gamma$-cadinene, $\delta$-cadinene, and unknown compounds A and $\mathrm{B}$. Tissue concentration $\left(\mu \mathrm{g} \mathrm{g}^{-1}\right.$ dry weight) of each terpene was calculated by dividing terpenoid concentration by the sample's tissue dry weight.

Compounds were identified based on previous work (Pezet et al. 2013), retention time comparison to analytical standards on the GC-FID, and comparison to chromatograms from gas chromatography-mass spectrometry on select samples (GCMS; Shimadzu GC-2010 and GCMS-QP2010 Plus with HP-5 column). References for mass spectrometry included a software library (Stein 2005), published reference (Adams 2009), and analytical standards (Sigma-Aldrich, Saint Louis, MO).

While previous research has described monoterpenes, sesquiterpenes, small phenolics, and green leaf volatiles in eastern hemlock (Lagalante and Montgomery 2003; Pezet et al. 2013), the present method captured only mono- and sesquiterpenes and their derivatives. Using analytical standards, we determined that our filtration step almost completely removed aromatic compounds, including benzyl alcohol and methyl salicylate. While quantification of these compounds was desirable, a consistent and clean filtration method was necessary for maintenance of the GC instruments over numerous samples.

Statistical Analyses. All statistical analyses were performed in R (version 2.15.2, R Development Core Team 2012). Current-year needle and twig tissue were analyzed separately, and each site was analyzed separately. Prior to analysis, outliers were identified and removed. Univariate outliers were defined as being over four standard 
deviations away from the mean in any one compound, and multivariate outliers were over 10x further from the centroid than $90 \%$ of the observations, based on Mahalanobis distance (McCune and Grace 2002). Compounds were removed from the analysis as insufficiently sampled if they were undetected in more than $20 \%$ of samples or if the raw quantity median was $10 \mathrm{pA}$ sec or less.

The resulting datasets contained twenty-two compounds, of which ten were present in twigs (Table 3A) and twenty-one present in needles (Table 3B). Two more variables were added, "total monoterpenes" and "total sesquiterpenes," representing the sum of concentrations of the fourteen monoterpenes and six sesquiterpenes in each sample, respectively. A logarithmic transformation of $\left(\log _{\mathrm{e}}(\mathrm{x}+1)\right)$ was applied to all concentration data and all HWA density data to improve normality.

Differences between resistant and control trees in concentrations of individual terpenoid compounds were identified using repeated measures ANOVA, followed by ANOVA of each month separately to identify seasonal patterns of resistance-correlated terpene chemistry. Multivariate differences in terpene profile were identified using MANOVA within each month. To test whether insect densities of HWA and elongate hemlock scale (EHS) confounded these results, HWA density and EHS categorical density rating were included as covariates in MANCOVA.

To further clarify the degree of confounding among explanatory variables, partitioning of variance was used to produce Venn diagrams displaying the percent of total variance explained uniquely by resistance status, HWA density, and EHS categorical density; the percent of total variance jointly explained by two or all three of the explanatory variables; and the percent of total variance not explained by the explanatory variables. Prior to partitioning of variance analysis, high collinearity among some terpenes was treated by removing terpenes from analysis if they were correlated with another terpene at Pearson's $r>0.70$. Selection of which correlated terpene to remove was based on AIC value and previous ANOVA results. Twelve compounds were retained for partitioning of variance in needle samples and seven in twig samples.

\section{RESULTS}

Single-Terpene Differences between Resistant and Susceptible Trees. Twigs from resistant trees tended to contain higher terpenoid concentrations, with the statistical significance of this trend differing by collection month 
and site (Table 3A). In the URI September and December twig collections, 9 of 10 and 10 of 10 compounds, respectively, were found at significantly higher concentrations (ranging from 1.1- to 4.2-fold) in resistant trees versus control trees (ANOVA, P<0.05, Table 3A). Similarly, in the NJ December twig collection, 5 of 10 compounds had significantly higher concentrations (1.5- to 3.5-fold) in resistant trees (ANOVA, $\mathrm{P}<0.05$, Table 3A).

Monoterpenes and sesquiterpenes in twigs appear equally likely to appear at high concentrations in resistant trees (Figure 1C, D). The twig collections noted above, URI September, URI December, and NJ December, show that the total concentration of monoterpenes and total concentration of sesquiterpenes were significantly higher (1.6 and 3.1 fold, respectively) in resistant versus control trees (ANOVA, $\mathrm{P}<0.05$, Table $3 \mathrm{~A}$ ). In other twig collections, total monoterpenes and total sesquiterpenes are not significantly different between resistant and control trees (ANOVA, P>0.10), although there is a consistent trend towards higher concentrations in resistant trees (Table $3 \mathrm{~A})$.

In needles, no consistent trend could be identified in individual or grouped terpenoid compounds. Although monoterpenes tended to appear at higher concentrations in resistant trees (Table 3B), neither total monoterpenes nor total sesquiterpenes differed significantly between resistant and control trees (ANOVA, P>0.10, Figure $1 \mathrm{~A}, \mathrm{~B}$ ). In the URI September needles collection, a trend of lower terpenoid concentrations in needles of resistant trees appeared, with 4 of 21 compounds having a significantly lower mean in resistant trees than in control trees $(A N O V A, P>0.05$, Table 3B). However, the trend was not repeated in other months and sites.

Repeated measures ANOVA analysis confirmed the connection between terpene concentration and resistance status. In twigs, total sesquiterpene concentration varied significantly with resistance at both sites, and total monoterpene concentration did so at the New Jersey forest site only (Table 4A). In twigs, 6 of 10 compounds varied significantly with resistance at both sites (Table 4A). In needles, results for total concentrations were inconsistent between sites. In needles, 6 of 21 compounds varied significantly with resistance at both sites (Table 4B). Terpene concentrations also varied significantly with month, especially in needles (Table 4B).

Multivariate Terpene Profiles with Resistance Status, HWA Density, and EHS Density. Resistance status explained a significant amount of variance in twig terpenoid concentrations from URI September and December collections (MANOVA, $\mathrm{P}<0.001$ in both cases). When HWA and EHS densities were included as cofactors in the analysis, resistance status remained a significant explanatory variable in these collections. In collections of twigs and needles from other months, resistance status only explained a significant part of variance of terpenoid concentrations 
when HWA and EHS densities were included as cofactors; we believe this is due to interactions between HWA, EHS, and resistance status. Notably, in most months, forest site resistant trees have zero or very low density infestations of HWA and EHS, while forest site control trees have a range of infestation densities; this creates a statistical interaction among HWA, EHS, and resistance status.

The partitioning of variance analysis separately displayed the unique and confounded explanatory power of these three variables in each collection (see Online Supplement). Resistance uniquely explained between $1 \%$ to $16 \%$ of the total variance in each month's collection, with HWA uniquely explaining $2 \%$ to $44 \%$ and EHS uniquely explaining $0.5 \%$ to $34 \%$ of the total variance. Confounded variance was greatest between resistance and HWA, ranging from $0 \%$ to $23 \%$ of the total variance in each month's collection. Interactions, displayed as negative percentages, were observed between resistance and HWA in 6 of 15 collections, and between resistance and EHS in 7 of 15 collections. Residual, unexplained variance was greater than $50 \%$ of total variance in all collections except needles of NJ June 2012. Results of partitioning of variance were not notably different between needle and twig collections.

\section{DISCUSSION}

Higher terpene levels in the twigs of HWA-resistant eastern hemlocks provide insight into possible mechanisms for observed resistance to adelgid infestation, although no evidence exists yet that the terpenes are the cause of resistance. The trend of 1.1- to 4-fold higher terpenoid concentrations in twigs of resistant trees, across all terpenoids and all seasons (Table 4A), suggests that the resistance mechanism does not rely on any changes or upregulation within the separate biosynthesis pathways for monoterpenoids or sesquiterpenoids (Bernard-Dagan 1982), but rather in the availability of their shared precursors, dimethylallyldiphosphate (DMADP) and isopentenyldiphosphate (IDP), or total availability of carbon. Although lack of herbivory on the resistant trees could cause greater carbon availability, the fact that the herbivore-free saplings in the URI common garden display an even stronger resistant-control difference suggests that herbivory is not the cause of the observed difference. The observation of increased terpenoid concentrations in twigs but not in needles of resistant hemlock is interesting because HWA feeds on nutrients in storage and transportation cells in the twig, the xylem ray parenchyma (Franceschi et al. 2005; Young et al. 1995). Previous studies have focused on terpene chemistry and nutrient content 
of the needles; following Pezet et al. (2013), this study included the twigs as HWA's direct feeding site.

There are two possible and non-mutually exclusive explanations for the higher terpene concentrations in the resistant trees. First, the growth-defense balance (Herms and Mattson 1992) in the resistant hemlocks may be altered, leading these trees to allocate more carbon toward constitutive defenses. Second, the resistant hemlocks may maintain greater or more available total carbon resources than susceptible hemlocks, resulting in more carbon available for both growth and defense, leading to the observed elevated concentrations of terpenoids in resistant trees.

The fact that we found the same trend of higher terpene concentrations in resistant trees in both forest trees and in the common garden saplings increases our confidence in our results. Specifically, having the common garden data allows us to reject the hypothesis that the observed differences are the result of variation in herbivory. Given only the forest site, it is plausible that greater herbivory on the control trees might deplete the tree's carbon resources and decrease terpene concentrations. Since all of the common garden saplings are herbivore-free, however, this idea cannot explain our results. In addition, environmental variables such as sunlight may influence terpene levels even between branches on a single forest tree (EA McKenzie and JS Elkinton, unpublished data), likely explaining some of the noise found by partitioning of variance analysis (Online Supplement). Because all of the common garden control and resistant saplings are located adjacent to each other within planting boxes, however, they are exposed to essentially identical environmental conditions. The consistency between the NJ forest and the URI common garden in rmANOVA results (Table 4A) and concentration trend (Table 3A) strongly support the correlation of increased terpenoid concentration in twigs with HWA-resistant status.

The difference between resistant and susceptible hemlock individuals appears to be a pattern across many terpenoids in twig tissue, rather than relying on one or several specific terpenoids. In comparing resistant individuals to susceptible individuals, an overall 1.1- to 4-fold higher mean concentration of both monoterpenoid and sesquiterpenoid compounds in twig tissue was observed consistently across seasons. This implies increased production of the terpene precursors DMADP and IDP, rather than changes at the level of individual terpene synthases. Such a broad change may possibly be due to greater carbon availability, or favered-allocation of carbon broadly toward defense rather than toward growth. Future research could distinguish these two options by comparing growth rate, water usage, and carbon assimilation between resistant and susceptible eastern hemlocks, and by determining whether phenolic defenses are also increased in the resistant trees. 
Without evidence of terpenoids directly affecting HWA health, we cannot conclude that the observed constitutive increase in twig terpenoid concentrations in twigs represents the resistance mechanism directly. Future research might determine the effect of specific terpenes on HWA, perhaps through induction of terpene production in susceptible eastern hemlocks or addition of terpenes to an artificial diet for HWA. The correlation of terpene concentrations with resistance status may assist individuals in developing cultivars of eastern hemlock resistant to HWA by providing a quicker and less expensive assay for resistance than inoculation trials with the insect.

Acknowledgments - We gratefully acknowledge Joshua Pezet for developing the chemical methods and Elwood Roberts for propagation of resistant trees. This work is supported by the United States Department of Agriculture National Institute of Food and Agriculture grant \#2010-03710 to ELP and JSE, and RI-AES Hatch Grant RI00HI-4004 to ELP and RAC. Access to the New Jersey forest sites was permitted through the New Jersey Department of Environmental Protection, Division of Fish \& Wildlife and the Delaware Water Gap National Recreation Area, National Parks Service.

\section{REFERENCES}

Adams RP (2009) Identification of Essential Oil Components by Gas Chromatography / Quadrupole Mass Spectroscopy. Allured Press, Illinois

Bentz S, Riedel L, Pooler M, Townsend A (2002) Hybridization and self-compatibility in controlled pollinations of eastern North American and Asian hemlock (Tsuga) species. J Arboriculture 28:200-205

Bernard-Dagan C, Pauly G, Marpeau A, Gleizes M, Carde JP, Baradat P (1982) Control and compartmentation of terpene biosynthesis in leaves of Pinus pinaster. Physiol Veg 20: 775-795

Broeckling CD, Salom SM (2003) Volatile emissions of eastern hemlock, Tsuga canadensis, and the influence of hemlock woolly adelgid. Phytochem 62: 175-180

Caswell TR, Casagrande R, Maynard B, Preisser EL(2008) Production and evaluation of eastern hemlocks potentially resistant to the hemlock woolly adelgid. In: Onken B, Reardon R (Eds.). $4^{\text {th }}$ Symposium on Hemlock Woolly Adelgid in the Eastern United States. USDA Forest Service, Hartford, pp.124-134

Domec JC, Rivera LN, King JS, Pezlen I, Hain F, Smith B, Frampton J (2013) Hemlock woolly adelgid (Adelges tsugae) infestation affects water and carbon relations of eastern hemlock (Tsuga canadensis) and Carolina hemlock (Tsuga caroliniana). New Phytol 199:452-463

Franceschi VR, Krokene P, Christiansen E, Krekling T (2005) Anatomical and chemical defenses of conifer bark against bark beetles and other pests. New Phytol 167:353-376 
Gomez S, Orians CM, Preisser EL (2012) Exotic herbivores on a shared native host: tissue quality after individual, simultaneous, and sequential attack. Oecologia 169: 1015-1024

Gonda-King L, Radville L, Preisser EL (2012) False ring formation in eastern hemlock branches: impacts of hemlock woolly adelgid and elongate hemlock scale. Environ Entomol 41: 523-531

Herms DA, Mattson WJ (1992) The dilemma of plants: to grow or defend. Quart Rev Biol 67: 283-335

Ingwell LL, Brady J, Fitzpatrick M, Maynard B, Casagrande R, Preisser EL (2009) Intraspecific variation in Tsuga canadensis foliar chemistry. Northeastern Naturalist 16: 585-594

Ingwell LL, Preisser EL (2011) Using citizen science programs to identify host resistance in pest-invaded forests. Cons Biol 25: 182-188

Lagalante AF, Montgomery ME (2003) Analysis of terpenoids from hemlock (Tsuga) species by solid-phase microextraction/gas chromatography/ion-trap mass spectrometry. J Agr Food Chem 51: 2115-2120

Lagalante AF, Montgomery ME, Calvosa FC, Mirzabeigi MN (2007) Characterization of terpenoid volatiles from cultivars of eastern hemlock (Tsuga canadensis). J Agr Food Chem 55: 10850-10856

Mattson WJ (1986) Protecting future forests from insects. In: J. J. Crowley (Ed.). 1986 Yearbook of Agriculture: Research for Tomorrow. USDA, Washington, D.C., pp 225-228

McClure MS (1989) Evidence of a polymorphic life cycle in the hemlock woolly adelgid, Adelges tsugae (Homoptera: Adelgidae). Ann Entomol Soc Am 82: 50-54

McClure MS (1991) Density-dependent feedback and population-cycles in Adelges tsugae (Homoptera: Adelgidae) on Tsuga canadensis. Environ Entomol 20: 258-264

McCune B, Grace JB, Urban DL (2002) Analysis of Ecological Communities. MjM Software Design, Gleneden Beach, Oregon, USA

Montgomery ME, Bentz SE, Olsen RT (2009) Evaluation of hemlock (Tsuga) species and hybrids for resistance to Adelges tsugae (Hemiptera: Adelgidae) using artificial infestation. J Econ Entomol 102: 1247-1254

Orwig DA, Foster DR (1998) Forest response to the introduced hemlock woolly adelgid in southern New England, USA. J Torrey Bot Soc 125: 60-73

Orwig DA, Foster DR, Mausel D (2002) Landscape patterns of hemlock decline in New England due to the introduced hemlock woolly adelgid. J Biogeog 29: 1475-1488

Oten KLF, Bauchan GR, Frampton J, Hain FP (2012) Biophysical characteristics of the stem and petiole surface of six hemlock (Tsuga) species and a hybrid: implications for resistance to Adelges tsugae. Botany 90: 11701178

Paradis A (2011) Population dynamics of the hemlock woolly adelgid (Hemiptera: Adelgidae). Dissertation, University of Massachusetts, Amherst, MA

Pezet J, Elkinton J, Gomez S, McKenzie EA, Lavine M, Preisser EL (2013) Hemlock woolly adelgid and elongate hemlock scale induce changes in foliar and twig volatiles of eastern hemlock. J Chem Ecol 39: 10901100 
R Development Core Team (2012) R 2.15.2: a language and environment for statistical computing. R Foundation for Statistical Computing, Vienna, Austria. http://www.R-project.org. Accessed 12 May 2013.

Radville L, Chaves A, Preisser EL (2011) Variation in plant defense against invasive herbivores: evidence for a hypersensitive response in eastern hemlocks (Tsuga canadensis). J Chem Ecol 37: 592-597

Reis P, Dix ME, Ielmini M, Thomas D (2004) National strategy and implementation plan for invasive species management. USDA Forest Service, Washington, D.C.

Schoettle AW, Klutsch JG, Sniezko RA (2012) Integrating regeneration, genetic resistance, and timing of intervention for the long-term sustainability of ecosystems challenged by non-native pests - a novel proactive approach. In: Proceedings of the $4^{\text {th }}$ International Workshop on Genetics of Host-Parasite Interactions in Forestry: General Technical Report. pp 112-123

Stein SE (2005) NIST Standard Reference Database 1a.NIST/EPA/NIH Mass Spectral Database (NIST05) and NIST Mass Spectral Search Program (NIST05s; Version 2.0g)

Vlot AC, Dempsey DA, Klessig DF (2009) Salicylic acid, a multifaceted hormone to combat disease. Annu Rev Phytopathol 47: 177-206

Wu J, Baldwin IT (2010) New insights into plant responses to the attack from insect herbivores. Annu Rev Genet 44 : $1-24$

Young R, Shields K, Berlyn G (1995) Hemlock woolly adelgid (Homoptera: Adelgidae): stylet bundle insertion and feeding sites. Ann Entomol Soc Am 88:827-835 


\section{TABLES}

Table 1: Collection dates and trees sampled at (a) the New Jersey forest site (mature trees) and (b) the University of Rhode Island common garden site (sapling trees).

\begin{tabular}{|c|c|c|}
\hline \multicolumn{3}{|c|}{ (a) New Jersey forest site } \\
\hline Collection Date & Resistant trees & Control trees \\
\hline May 2012 & $\# 1-5$ & 5 total; three locations $1-5 \mathrm{~km}$ away \\
\hline June 2012 & $\# 1-5$ & 6 total; three locations $1-5 \mathrm{~km}$ away \\
\hline October 2012 & $\# 1-7$ & 21 total; 4 within the stand, 5 on the slope, 12 at two locations $5 \mathrm{~km}$ away \\
\hline December 2012 & $\# 1-7$ & 16 total; 3 within the stand, 6 on the slope, 7 at $5 \mathrm{~km}$ away \\
\hline April 2013 & $\# 1-7$ & 17 total; 3 within the stand, 7 on the slope, 7 at $5 \mathrm{~km}$ away \\
\hline June 2013 & $\# 1-7$ & $\begin{array}{l}15 \text { total; } 3 \text { within the stand, } 6 \text { on the slope, } 6 \text { at } 5 \mathrm{~km} \text { away, } 8 \text { at } 6.5 \mathrm{~km} \\
\text { away, } 7 \text { at } 1 \mathrm{~km} \text { away }\end{array}$ \\
\hline \multicolumn{3}{|c|}{ (b) University of Rhode Island common garden site } \\
\hline Collection Date & Resistant trees & Control trees \\
\hline July 2012 & $\begin{array}{l}5 \text { clones each for } \\
\text { resistant \#1-5 }\end{array}$ & 10 Massachusetts saplings, 9 Pennsylvania saplings \\
\hline September 2012 & $\begin{array}{l}5 \text { clones each for } \\
\text { resistant \#1-5 }\end{array}$ & 10 MA saplings, 9 PA saplings \\
\hline December 2012 & $\begin{array}{l}5 \text { clones each for } \\
\text { resistant \#1-5 }\end{array}$ & 10 MA saplings, 9 PA saplings \\
\hline
\end{tabular}


Table 2: Relative terpenoid concentrations in (a) twigs and (b) needles. Number indicates ratio of Resistant trees over Control trees average concentrations. Dark gray shading indicates higher concentration in Resistant, light gray indicates lower concentration in Resistant. Marginal significance $(P<0.10)$ by ANOVA is indicated by italics and asterisk, full significance $(P<0.05)$ by bold italics and asterisk.

(a) Twigs: ratios for Resistant trees to Control trees

\begin{tabular}{|c|c|c|c|c|c|c|c|}
\hline TWIGS & $\begin{array}{l}\text { N J June } 2012 \\
R \text { to C ratio }\end{array}$ & $\begin{array}{l}\text { NJ Oct } 2012 \\
\text { R to C ratio }\end{array}$ & $\begin{array}{l}\text { NJ Dec } 2012 \\
\text { R to C ratio }\end{array}$ & $\begin{array}{l}\text { NJ April } 2013 \\
\text { R to C ratio }\end{array}$ & $\begin{array}{l}\text { NJ June } 2013 \\
R \text { to C ratio }\end{array}$ & $\begin{array}{l}\text { URI Sept } 2012 \\
\text { R to C ratio }\end{array}$ & $\begin{array}{l}\text { URI Dec } 2012 \\
\text { R to C ratio }\end{array}$ \\
\hline Tricyclene & $0.75^{\circ}$ & 1.28 & 2.00 & 1.19 & 1.92 & $1.70^{*}$ & $1.09 *$ \\
\hline a-Pinene & 1.06 & 1.20 & $1.49^{*}$ & 1.49 & 1.07 & $1.92 *$ & $1.49 *$ \\
\hline Camphene & 0.78 & 1.45 & 1.94 & 1.46 & $1.58^{\circ}$ & $2.80^{*}$ & $2.26 *$ \\
\hline B-Pinene & 1.14 & $1.41^{\circ}$ & $1.67^{*}$ & 2.40 & 1.18 & $2.55 *$ & $2.24 *$ \\
\hline Myrcene & 0.96 & 1.16 & $2.18 *$ & 2.28 & 1.13 & $3.79 *$ & $1.95 *$ \\
\hline Limonene & 1.12 & $1.49 *$ & $1.25^{*}$ & $1.28 *$ & $1.15^{\circ}$ & $1.65 *$ & 1.23 \\
\hline Bomyl Acetate & $0.77^{\circ}$ & 1.07 & 1.04 & $0.82^{\circ}$ & $1.51^{*}$ & $2.04 *$ & $1.84 *$ \\
\hline B-Caryophyllene & 0.96 & 2.00 & $3.50 *$ & 1.86 & 0.97 & 2. $20^{*}$ & $2.63 *$ \\
\hline a-Humulene & 0.93 & $1.83^{*}$ & $2.63 *$ & 1.65 & 0.98 & $2.08 *$ & $2.34 *$ \\
\hline Germacrene D & $\mathrm{n} / \mathrm{a}$ & $3.18^{*}$ & $3.22 *$ & 1.93 & 1.06 & $1.65^{*}$ & $4.18 *$ \\
\hline total mono & 0.94 & 1.22 & $1.57^{*}$ & 1.49 & 1.13 & $2.25 *$ & $1.59 *$ \\
\hline total sesqui & 0.94 & $2.45^{*}$ & $3.11 *$ & 1.82 & 1.02 & $1.98^{*}$ & 2.91 \\
\hline
\end{tabular}

(b) Needles: ratios for Resistant trees to Control trees

\begin{tabular}{|c|c|c|c|c|c|c|c|c|c|}
\hline NEEDLES & $\begin{array}{l}\text { NJ May } 2012 \\
\text { R to C ratio }\end{array}$ & $\begin{array}{l}\text { NJ June } 2012 \\
\text { R to C ratio }\end{array}$ & $\begin{array}{l}\text { NJ Oct } 2012 \\
\text { R to C ratio }\end{array}$ & $\begin{array}{l}\text { NJ Dec } 2012 \\
\text { R to C ratio }\end{array}$ & $\begin{array}{l}\text { NJ April } 2013 \\
\text { R to C ratio }\end{array}$ & $\begin{array}{l}\text { NJ June } 2013 \\
R \text { to } C \text { ratio }\end{array}$ & $\begin{array}{l}\text { URI July } 2012 \\
\text { R to C ratio }\end{array}$ & $\begin{array}{l}\text { URI Sept } 2012 \\
\text { R to C ratio }\end{array}$ & $\begin{array}{l}\text { URI Dec } 2012 \\
\text { R to C ratio }\end{array}$ \\
\hline Tricyclene & 1.08 & 1.02 & 1.09 & 0.96 & 1.06 & 1.14 & 1.17 & 0.98 & 1.12 \\
\hline a-Pinene & 1.23 & 1.17 & 1.17 & 1.03 & 1.11 & 1.09 & 1.13 & 0.95 & 1.07 \\
\hline Camphene & 1.04 & 1.13 & 1.11 & 0.99 & 1.05 & 1.14 & 1.15 & 0.96 & 1.07 \\
\hline Sabinene & 1.16 & 1.04 & $1.21^{*}$ & 1.15 & 1.37 & 1.10 & 1.15 & 0.87 & 0.93 \\
\hline B-Pinene & 1.20 & 0.98 & 1.18 & 1.13 & 1.22 & 1.12 & 1.10 & 0.96 & 1.11 \\
\hline a-Phellandrene & 1.36 & 1.23 & $1.30^{\circ}$ & $1.18^{\circ}$ & 1.30 & 1.78 & $1.25 *$ & 0.89 & 1.19 \\
\hline p-Cymene & 1.48 & 0.94 & $1.18^{*}$ & 1.09 & 1.07 & 1.35 & 1.10 & 0.93 & 0.95 \\
\hline Limonene & 1.04 & 0.89 & 1.12 & 1.05 & 1.10 & 1.08 & 0.89 & 0.88 & 1.02 \\
\hline Eucalyptol & 0.90 & $0.32 *$ & 1.04 & 1.21 & $1.71^{\circ}$ & 0.38 & 0.64 & 0.73 & 0.75 \\
\hline Camphor & 1.27 & $0.57 *$ & 0.84 & 0.90 & 0.96 & $4.08^{*}$ & 1.09 & 0.85 & 1.04 \\
\hline Piperitone & 0.91 & $0.57 *$ & 1.16 & 1.12 & 0.87 & $\mathrm{n} / \mathrm{a}$ & 0.74 & 0.73 & 0.99 \\
\hline Unknown A & $\mathrm{n} / \mathrm{a}$ & $\mathrm{n} / \mathrm{a}$ & 0.93 & 0.82 & $0.76^{*}$ & 0.94 & n/a & $0.76^{*}$ & $0.89^{\circ}$ \\
\hline Unknown B (Ac.) & $\mathrm{n} / \mathrm{a}$ & $\mathrm{n} / \mathrm{a}$ & $0.44^{\circ}$ & 0.79 & 0.60 & 0.37 & $0.50^{\circ}$ & $0.37^{*}$ & 0.57 \\
\hline B-Caryophyllene & 1.24 & 1.07 & 1.06 & 1.03 & 1.03 & 1.07 & 1.03 & 0.84 & 0.94 \\
\hline a-Humulene & 1.23 & 1.05 & 1.04 & 1.03 & 1.02 & 1.06 & 1.03 & 0.84 & 0.94 \\
\hline y-Muurolene & $n / a$ & $\mathrm{n} / \mathrm{a}$ & $1.18^{\circ}$ & 1.13 & 1.06 & 0.97 & 0.90 & 0.89 & 1.04 \\
\hline Germacrene D & $n / a$ & $\mathrm{n} / \mathrm{a}$ & $1.39^{*}$ & $3.36^{*}$ & $2.44^{*}$ & 0.90 & 1.21 & 0.92 & 1.11 \\
\hline$y$-Cadinene & $\mathrm{n} / \mathrm{a}$ & $\mathrm{n} / \mathrm{a}$ & $1.09^{*}$ & 0.97 & 0.93 & 0.93 & 0.85 & $0.79^{*}$ & 0.92 \\
\hline d-Cadinene & $\mathrm{n} / \mathrm{a}$ & $\mathrm{n} / \mathrm{a}$ & $1.10^{\circ}$ & 1.03 & 1.01 & 0.93 & 1.06 & $0.81^{*}$ & 0.96 \\
\hline total mono & 1.05 & 1.01 & 1.12 & 1.02 & 1.06 & 1.11 & 1.08 & 0.93 & 1.05 \\
\hline total sesqui & 1.24 & 1.05 & $1.07^{\circ}$ & 1.06 & 1.04 & 1.03 & 1.05 & $0.84^{\circ}$ & 0.95 \\
\hline
\end{tabular}


Table 3: Partitioning of variance across terpenoid compounds. Total variance across 12 terpenoid compounds in needles or seven compounds in twigs is attributed to explanatory variables: Resistance status of sample, HWA density on sample tissue, EHS density on sample tissue. Correlation is represented by the percent of total variance uniquely attributed to a given variable. Confounded variables share a percent of total variance, jointly explained by both variables. Statistical interactions are represented by negative joint variance. Noise is represented by the percent of total variance left unexplained by the measured variables.

\begin{tabular}{|c|c|c|c|c|c|c|}
\hline Collection & $\begin{array}{l}\text { Resistance: } \\
\text { variance } \\
\text { attributed to } \\
\text { Res only }\end{array}$ & $\begin{array}{l}\text { HWA: } \\
\text { variance } \\
\text { attributed to } \\
\text { HWA only }\end{array}$ & $\begin{array}{l}\text { EHS: } \\
\text { variance } \\
\text { attributed to } \\
\text { EHS only }\end{array}$ & $\begin{array}{l}\text { Confounded: } \\
\text { Resistance and } \\
\text { HWA joint } \\
\text { variance }\end{array}$ & $\begin{array}{l}\text { Confounded: } \\
\text { Resistance and } \\
\text { EHS joint } \\
\text { variance }\end{array}$ & $\begin{array}{l}\text { Noise: } \\
\text { unexplained } \\
\text { variance }\end{array}$ \\
\hline $\begin{array}{l}\text { NJ June } 2012 \\
\text { twigs }\end{array}$ & $7 \%$ & $5 \%$ & $34 \%$ & interaction & interaction & $58 \%$ \\
\hline $\begin{array}{l}\text { NJ Oct } 2012 \\
\text { twigs }\end{array}$ & $7 \%$ & $6 \%$ & $3 \%$ & interaction & interaction & $85 \%$ \\
\hline $\begin{array}{l}\text { NJ Dec } 2012 \\
\text { twigs }\end{array}$ & $16 \%$ & $3 \%$ & $10 \%$ & $2 \%$ & interaction & $72 \%$ \\
\hline $\begin{array}{l}\text { NJ April } 2013 \\
\text { twigs }\end{array}$ & $7 \%$ & $7 \%$ & $8 \%$ & $0 \%$ & interaction & $64 \%$ \\
\hline $\begin{array}{l}\text { NJ June } 2013 \\
\text { twigs }\end{array}$ & $2 \%$ & $7 \%$ & $n / a$ & interaction & $n / a$ & $92 \%$ \\
\hline $\begin{array}{l}\text { URI Sept } \\
2012 \text { twigs }\end{array}$ & $14 \%$ & $3 \%$ & $4 \%$ & interaction & interaction & $82 \%$ \\
\hline $\begin{array}{l}\text { URI Dec } 2012 \\
\text { twigs }\end{array}$ & $12 \%$ & $n / a$ & $1 \%$ & $n / a$ & $1 \%$ & $86 \%$ \\
\hline $\begin{array}{l}\text { NJ May } 2012 \\
\text { needles }\end{array}$ & $1 \%$ & $n / a$ & $2 \%$ & $n / a$ & $1 \%$ & $96 \%$ \\
\hline $\begin{array}{l}\text { NJ June } 2012 \\
\text { needles }\end{array}$ & $12 \%$ & $44 \%$ & $3 \%$ & $23 \%$ & $0 \%$ & $19 \%$ \\
\hline $\begin{array}{l}\text { NJ Oct } 2012 \\
\text { needles }\end{array}$ & $11 \%$ & $8 \%$ & $1 \%$ & interaction & $0 \%$ & $83 \%$ \\
\hline $\begin{array}{l}\text { NJ Dec } 2012 \\
\text { needles }\end{array}$ & $6 \%$ & $6 \%$ & $3 \%$ & $1 \%$ & $3 \%$ & $82 \%$ \\
\hline $\begin{array}{l}\text { NJ April } 2013 \\
\text { needles }\end{array}$ & $9 \%$ & $10 \%$ & $2 \%$ & $3 \%$ & $0 \%$ & $61 \%$ \\
\hline $\begin{array}{l}\text { NJ June } 2012 \\
\text { needles }\end{array}$ & $4 \%$ & $3 \%$ & $n / a$ & $0 \%$ & $n / a$ & $94 \%$ \\
\hline $\begin{array}{l}\text { URI Sept } \\
2012 \text { needles }\end{array}$ & $5 \%$ & $2 \%$ & $1 \%$ & interaction & interaction & $93 \%$ \\
\hline $\begin{array}{l}\text { URI Dec } 2012 \\
\text { needles }\end{array}$ & $2 \%$ & $n / a$ & $2 \%$ & $n / a$ & interaction & $96 \%$ \\
\hline
\end{tabular}




\section{FIGURES}

(a) Concentrations in Res vs. Ctrl trees:

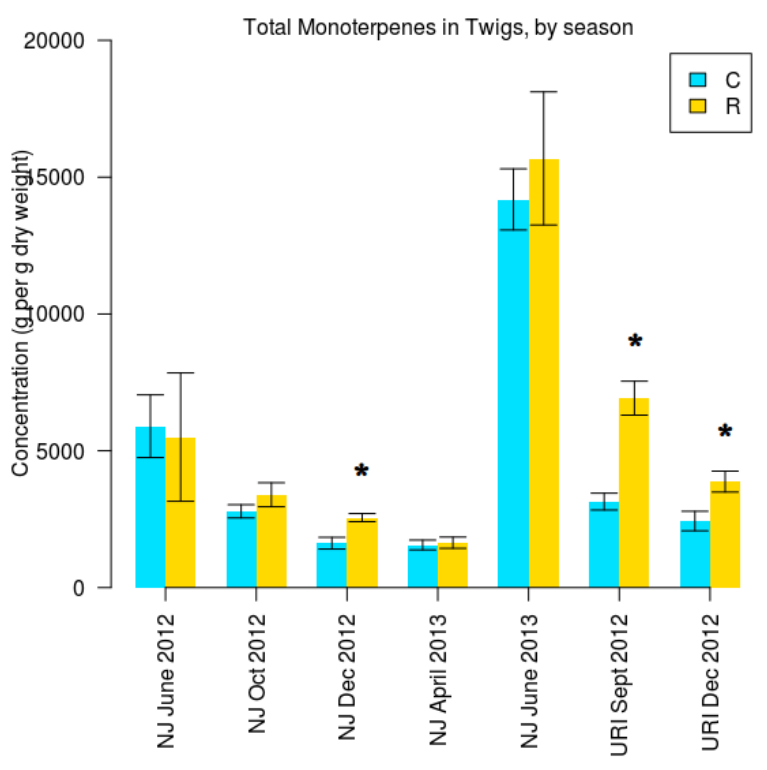

(c)

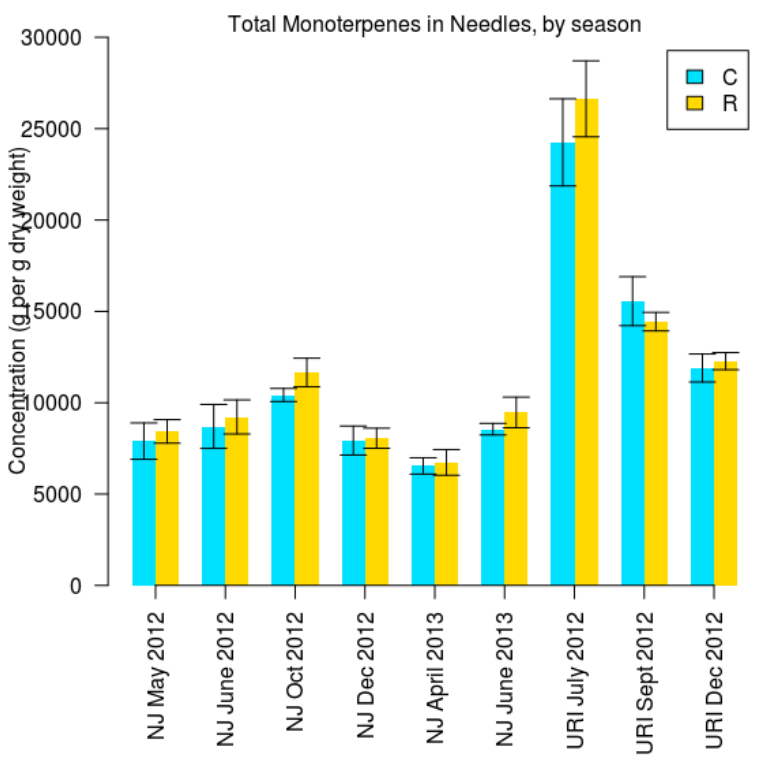

(b) Concentrations in Res vs. Ctrl trees:

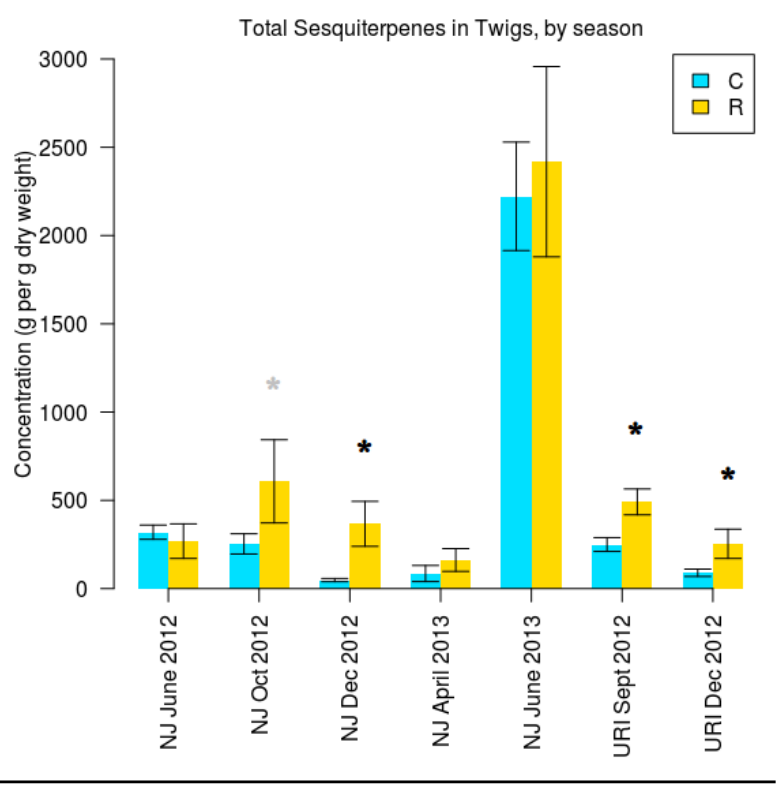

(d) Concentrations in Res vs. Ctrl trees:

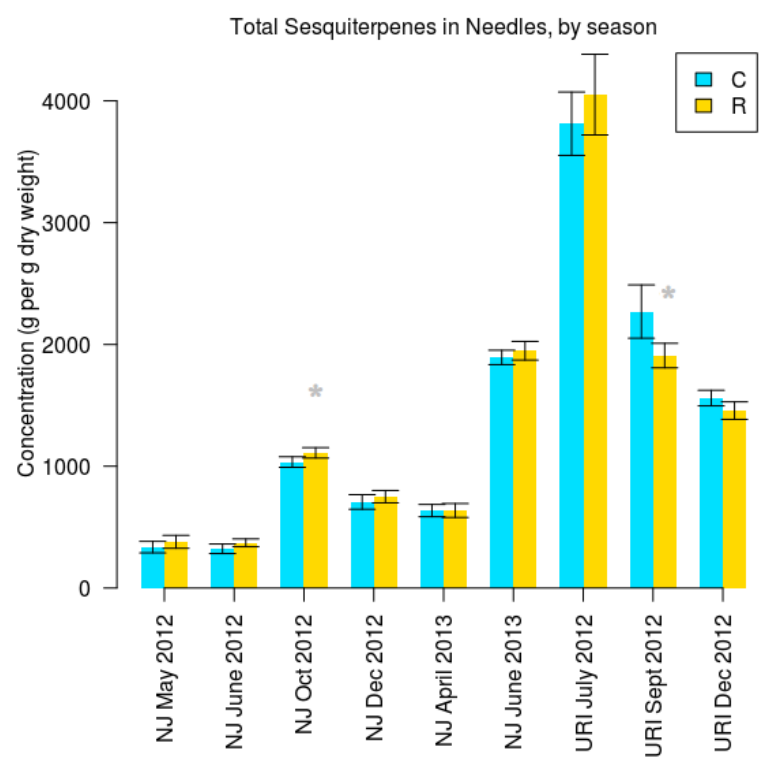

Figure 1: Relative total concentrations of all monoterpenes, or all sesquiterpenes. Bar displays average concentration in Control (blue) or Resistant (gold) trees. Error bars display standard error. Marginal significance $(P<0.10)$ by ANOVA is marked by a gray asterisk, full significance $(P<0.05)$ by a black asterisk.

$(a \& b)$ Monoterpenes and sesquiterpenes in needles; $(c \& d)$ monoterpenes and sesquiterpenes in twigs. 